\title{
The Role of Contracts and Networks in Public Governance: The Importance of the "Social Epistemology" of Decision Making
}

\author{
Karl-Heinz Ladeur \\ University of Hamburg
}

Follow this and additional works at: https://www.repository.law.indiana.edu/ijgls

Part of the Contracts Commons, Government Contracts Commons, and the International Law

Commons

\section{Recommended Citation}

Ladeur, Karl-Heinz (2007) "The Role of Contracts and Networks in Public Governance: The Importance of the "Social Epistemology" of Decision Making," Indiana Journal of Global Legal Studies: Vol. 14 : Iss. 2 , Article 7.

Available at: https://www.repository.law.indiana.edu/ijgls/vol14/iss2/7

This Symposium is brought to you for free and open access by the Law School Journals at Digital Repository @ Maurer Law. It has been accepted for inclusion in Indiana Journal of Global Legal Studies by an authorized editor of Digital Repository @ Maurer Law. For more information, please contact rvaughan@indiana.edu.

\section{$\Psi$}

JEROME HALL LAW LIBRARY

INDIANA UNIVERSITY

Maurer School of Law
Blooming ton 


\title{
The Role of Contracts and Networks in Public Governance: The Importance of the "Social Epistemology" of Decision Making
}

\author{
KaRL-Heinz Ladeur ${ }^{*}$
}

\begin{abstract}
This article addresses the role of public contracts and of public-private networks in relation to the new cognitive infrastructure of postmodern societies and the rise of an experimental rationality. The use of contracts in public law has evolved: it is no longer just a new version of the administrative decision; it is now used as a means in a broad process of breaking up the permeability of public administration. New modes of contracting are a response to increasing fragmentation of interests in industry and in society as a whole. This evolution has also given rise to the concept of the "network society." Certain normative challenges have to be met in postmodern administration. The administrative act is always limited by the effect of the framing of the observations and the rules that make up the social epistemology and the cognitive infrastructure of society, which are applied and not reflected in the administrative processes. The search for the role of the contract in public administration is not productive; it is more important to have a better understanding of its embedding in the relationships between public and private actors on the one hand and the social epistemology that dominates both the private and the public use of common knowledge in society on the other.
\end{abstract}

\section{Public Contracting and the Rise of the Network Society}

Public decision making has always been closely linked to a cognitive mode of generation of facts, referring to plausibility standards, proof rules, and so forth. This article tries to demonstrate that the role of public contracts and of public-private networks, in particular, can only be understood if the new cognitive infra-

\footnotetext{
- Professor of Public Law, University of Hamburg.
} 
structure of postmodern societies and the rise of an experimental rationality are considered.

\section{A. Regulation as the Precursor of Public Contracting}

In Europe and in North America, we can observe the increasing reference to the concepts of contract and network in public law, which used to be dominated by the centrality of the "decision" unilaterally taken by a public agency. The concept of a "public contract" seems to have been sufficiently structured by traditional legal doctrine in spite of its lesser importance in administrative practice. The concept of "network" is relatively new_-at least in legal research" — but is spreading rapidly in different versions, as we will see later. Even at first sight, one can realize that it lacks conceptual clarity-although this observation does not exclude the notion from further reflection. At a closer look, we will see that the same is true for the concept of the public contract: in the past, its role in administrative procedures was marginal; it was used in a kind of secondary remodeling of the unilateral administrative decision to allow for more flexibility - this is at least true for European continental public law. ${ }^{2}$

However, the use of the form of contract in public law has undergone a silent evolution. It is no longer just a new version of the administrative decision. It is now used as a means in a broad process of breaking up the permeability of public administration—-this process took place earlier in American administrative law,

1. Karl-Heinz Ladeur, Towards a Legal Concept of the Network in European Standard-Setting, in EU Commitrees: Social Regulation, Law and Politics 151, 161-64 (Christian Joerges \& Ellen Vos eds., 1999). For a discussion on the use of the network concept in administrative science, see Donald F. Kettr, The Transformation of Governance: Public Administration for Twenty-First Century America 112-13 (2002). For a discussion on networks and knowledgesharing in public administration, see Stephen Goldsmith \& William D. Eggers, Governing by Network: The New Shape of the Public Sector 106-11 (2004) (arguing in favor of using networks for knowledge generation in public administration). For a discussion on networks and the "architecture of complexity," see Albert-László Barabásı, Linked: The New Science of Networks 201-02 (2002); The Structure and Dynamics of Networks (Mark Newman, AlbertLászló Barabási \& Duncan J. Watts eds., 2006) (containing articles which give an introduction to mainly mathematical and scientific use of network theory); Walter W. Powell, The Capitalist Firm in the Twenty-First Century: Emerging Patterns in Western Enterprise, in The Twenty-First-Century Firm: Chancing Economic Organization in International Perspective 33, 33-37 (Paul DiMaggio ed., 2001) (describing the evolution of the organization of firms under postmodern conditions of production).

2. 1 Otto Mayer, Deutsches Verwaltuncsrecht 50 (lst ed., 1895). 
from the inception of the new task of regulation onward. ${ }^{3}$ However, we will see that the more structured processes of regulation in the welfare state presupposed the increasing role of "representative" organizations of industry in particular, whereas the new modes of contracting are a response to the increasing fragmentation of interests both in industry and in society as a whole. ${ }^{4}$ This evolution, which has its roots in society, has also given rise to the concept of the "network society," which, first of all, pre-supposes the weakening of the traditional integrative function of the representative organizations and, above all, a more direct contact of firms and groups of firms with administration. ${ }^{6}$ The rise of the network society and the crisis of modern centralized regulation has also fundamentally changed the role of the contract, despite the fact that doctrine has not yet reacted in an appropriate way because the form of the "public contract" does not seem to have changed at all. ${ }^{8}$ This rather anecdotal observation might at least make a theoretical look at the evolution of both concepts plausible, because the rise of one concept-that of network-seems to be closely linked to the transformation of the role of the other concept- that of the public contract.

3. See generally Richard B. Stewart, Administrative Law in the Twenty-First Century, 78 N.Y.U. L. Rev. 437 (2003) (discussing the rise of administrative regulation); Richard B. Stewart, U.S. Administrative Law: A Model for Global Administrative Law?, 68 Law \& Contemp. Probs. 63 (Sum/ Aut 2005) (discussing the traditional model of administrative law and how it has developed subsequently).

4. See Goldsmith \& Egcers, supra note 1 , at 28.

5. See generally 1 Manuel Castells, The Information Age: Economy, Society and Culture: The Rise of the Network Society (1996) (giving an overview of the transformation of society in the information age that is increasingly organized around networks).

6. Renate Mayntz, Modernization and the Logic of Interorganizational Networks, 6 K NowledGE \& Pol'y 3, 5 (1993).

7. See Peer Zumbansen, Ordnungsmuster im Modernen Wohlfahrtsstaat: Lernerfahrungen Zwischen Staat, Gesellschaft und Vertrac (2000) (giving an overview of the relationship between public and private forms of decisionmaking in the modern welfare state). See generally Karl-Heinz Ladeur, The Changing Role of the Private in Public Governance: The Erosion of Hierarchy and the Rise of a New Administrative Law of Cooperation. A Comparative Approach (European Univ. Inst., Working Paper LAW No. 2002/9, 2002) (describing the evolution of the doctrine of administrative law).

8. The German government has asked Professors Gunnar F. Schuppert and Jan Ziekow to draw up a statute on new forms of public-private cooperation, intended to adapt traditional public contract law to new functions. Gunnar Folke Schuppert, Verwaltungskooperationsrecht (Public Private Partnerships) (2001), available at http://www.staat-modern.de/Anlage/ original_548354/Gutachten-Prof.-Dr.-Schuppert.pdf. 


\section{B. The Fragmentation of the State and the New Governance Model}

At first, the concept of network in legal sociology was used in a descriptive sense: a public or public-private network in this sense is a mode of continual cooperation among public agencies, which extends beyond hierarchy and may also include private actors. ${ }^{9}$ The latter version, in particular, allows for the renewed importance of the contract-however, one should not overlook the administrative contract as a mode of interaction among public agencies. The new role of heterarchical networks comes to the fore, especially in the European Union, because more and more transnational forms of direct cooperation among public authorities, which lie beyond traditional international cooperation at the level of governments, are spreading rapidly. ${ }^{10}$ Anne-Marie Slaughter has referred to this evolution as the "disaggregated state." In the European Union, this phenomenon can be attributed to the development of a "third level" of decision making which goes beyond the national and supranational forms. Yet this recent evolution is not confined to the European Union; it can also be observed both in transnational interrelationships and also within states. ${ }^{12}$ More and more complex tasks, which demand special expertise in social policy, are organized in informal networks of public agencies, although the formal competencies of decision making toward external subjects mostly remain untouched. Thus, the new potential of networks to a certain extent remains in the shadow of hierarchy and does not fully develop its innovative capabilities. The heterarchical character of this type of administrative decision making allows for new forms of breaking the impermeability of the state, which has, of course, been much stronger on the European continent than in the Anglo-American domain. The new phenomena of networking cannot be separated easily from "negotiated regulation"13 (regulierte Selbstregulierung), which is also quite familiar to both American and European law. The main difference may lie in the fact that this version of administrative action still tries to adhere to

9. See KetTL, supra note 1 , at 167.

10. For a discussion on the complex regulation of telecommunication, which integrates national, transnational and supranational elements, see Karl-Heinz Ladeur \& Christoph Möllers, Der europäische Regulierungsverbund der Telekommunikation im deutschen Verwaltungsrecht, 120 DEUTsches Verwaltungsblatt 525 (2005).

11. Anne-Marie Slaughter, A New World Order 12 (2004).

12. For a discussion on knowledge generation in standard setting, see Ladeur, supra note 1 , at 161-64.

13. For a discussion on the role of information in postmodern processes of rulemaking, see Daniel P. Selmi, The Promise and Limits of Negotiated Rulemaking: Evaluating the Negotiation of a Regional Air Quality Rule, 35 Envtr. L. 415, 448 (2005). 
the established role of regulation and its focus on the process of steering society. In this weaker version, it lies in a mode of imposing broad tasks that can be readapted to changing situations and specific requirements. Often, this separation of public goals and its self-regulated implementation in concrete cases is nothing but an illusion and reduces the state to a marginal role as moderator, ${ }^{14}$ or one of "management by exception."

As a more comprehensive concept for these new forms of public action, governance is increasingly used in legal sociology and even in administrative law. ${ }^{15}$ The rise of governance is also due to the transformation of regulation, which still presupposed a steering role of the competent public agency, which seemed not to be called into question by the systematic participation of private actors. Public hearings were regarded as a structured procedure ${ }^{16}$ that allowed for rational balancing of interests by a public agency in a general way. The rise of the concept of governance reflects the transformation of this regulatory logic: governance describes a field of action within which there is no longer a clear separation of the subject and the object of a regulation. ${ }^{17}$

These preliminary remarks have not brought us very far. Up to now, the liter-

14. See François Moreau, The Role of the State in Evolutionary Economics, 28 CaMBRIDGE J. Econ. 847, 866 (2004).

15. See generally Christoph Möllers, European Governance-Meaning and Value of a Concept (Georg-August-Universität Göttingen, Working Paper No. 40, 2006), available at http://www.europarecht.uni-goettingen.de/Paper40.pdf (describing the use of the concept of "governance" for the analysis of new processes of decisionmaking in the EU). For other perspectives on governance, see KETTL, supra note 1, at 140-42 (discussing the use of governance in managing environmental policy); Carolyn J. Hill \& Laurence E. Lynn, Jr., Is Hierarchical Governance in Decline? Evidence from Empirical Research, 15 J. Pub. Admin. Res. \& Theory 173 (2005) (discussing the rise of "governance" as an organizing concept for public administration reform); Orly Lobel, The Renew Deal: The Fall of Regulation and the Rise of Governance in Contemporary Legal Thought, 89 MINN. L. REv. 342 (2004) (analyzing the shift from the assumption of a stable frame of reference for regulation to a more open concept of cooperative decisionmaking).

16. See Stewart, Administrative Law in the Twenty-First Century, supra note 3, at 441.

17. This is due to the broader definition of administrative tasks. See KeTtL, supra note 1, at 129; Ruth Hoogland DeHoog, 66 Pub. Admin. Rev. (Theory to Practice), May/June 2006, at 68, 70 (commentary on Trever L. Brown, Matthew Potoski \& David M. Van Slyke, Managing Public Service Contracts: Aligning Values, Institutions, and Markets, 66 Puв. Admin. Rev. 323 (2006)); Orly Lobel, Formulating a New Paradigm: Newness and Ripeness of the Moment, in Joel Handler, Orly Lobel, Elizabeth Mertz, Edward Rubin \& William Simon, A Roundtable on New Legal Realism, Microanalysis of Institutions, and the New Governance: Exploring Convergences and Differences, 2005 WIs. L. Rev. 479, 492 ("And, I have become increasingly interested in what I view as new governance in action, as a 'third way' between regulation and market solutions."). 
ature, including the descriptive use of the concepts of network and governance, has not been very promising either.

\section{The Transformation of the Cognitive Infrastructure of Deci- sion Making and its Normative Repercussions}

\section{A. From Practical Experience to Reflexive Standardization}

Let us interrupt these conceptual reflections and turn to the question of which normative challenges have to be met in postmodern administration. The new comprehensive approach will allow for more flexibility, more decentralization, and more participation - this idea is quite widespread in the U.S. literature. ${ }^{18}$ From a legal perspective, this assumption raises a new question: that of public accountability, said to guarantee democratic responsibility, in administrative or public-private networks that extend beyond hierarchy. ${ }^{19}$ We will have to come back to this question later. It might be more productive at this stage of our reflections to assume that the new phenomena of networking are a consequence of a more basic transformation of the knowledge basis of society and that they reflect the necessity of using different types of new knowledge. Freeman and Farber ${ }^{20}$ go a step further and epitomize the new function of procedure in administrative action: the new mode of problem solving is characterized as being "modular." This means that administration is now changing from "sharp" administrative acts to reflexive and incremental procedures which are meant to generate new knowledge by entangled levels of design, action, revision, and evaluation within a complex, time-dependent process of management. Separate aspects of environmental protection, for example, are no longer treated according to different statutes, but

18. For an administrative law perspective, see Jody Freeman, The Private Role in Public Governance, 75 N.Y.U. L. Rev. 543, 649-53 (2000).

19. Id. at 579; Colin Scott, Accountability in the Regulatory State, 27 J. Legal Stud. 38, 40 (2000).

20. Jody Freeman \& Daniel A. Farber, Modular Environmental Regulation, 54 Duke L.J. 795 (2005). For a general overview of the differences between traditional regulation and the new forms of contracting, see Jody Freeman, The Contracting State, 28 FLA. St. U. L. Rev. 155 (2000). For a discussion on the relationship between regulation and the new model of governance, see Peter Vincent-Jones, The New Public Contracting: Regulation, Responsiveness, Relationality 77 (2006). 
are integrated into a holistic strategy of problem solving which use different types of experience, expertise, and experiments. ${ }^{21}$

This description brings together several important elements of contractual arrangements and of interaction in networks. However, there are still some open questions: For what reason did this new interest in both concepts come to the fore? Why has it emerged only recently? Why did it not emerge earlier? The interest in flexibility and participation is far from a new phenomenon. There was always a strong interest in the flexibility of administrative action, which was served by granting a leeway of discretion to administration. Informal action of administrative agencies is nothing new either.

To my mind, the innovation is, in fact, to be found in the informational aspects of, and processing in, decision making. In the U.S. literature, a sequential model of knowledge generation and processing has been forwarded by Richard Stewart. According to this author, administrators in the nineteenth century followed a model of "trial-type adjudicatory hearings," which was supplanted by a "broad process" of knowledge generation by a "government of experts."2 One might add that the first epoch of liberal administration was characterized by a strong orientation toward experience as a type of general knowledge that was generated from practice and distributed to many people, ${ }^{23}$ while expert knowledge is more linked to specialized groups, professional communities, and bigger enterprises. Hand in hand with this transformation, the reflexivity of knowledge increases and gives room to the new role of experts, who no longer systematize and generalize shared and distributed knowledge as in the past, but create new technological and economic strategies of creating new knowledge both for and through technical processes. This reflexivity finds its repercussion in the formulation of general standards of safety, while in the past, the question of "how safe is safe enough" was interpreted by experts on a case-by-case basis using their gen-

21. See Lobel, supra note 15, at 374; Charles F. Sabel \& Jonathan Zeitlin, Presentation at the International Conference of the Hellenic Presidency of the European Union in Ioannina, Greece on the Modernisation of the European Social Model and EU Policies and Instruments: Active Welfare, Experimental Governance, Pragmatic Constitutionalism: The New Transformation of Europe (May 21-22, 2003) 19 (transcript available at http://www.eucenter.wisc.edu/OMC/papers/ EUC/ZeitlinSabel).

22. Stewart, Administrative Law in the Twenty-First Century, supra note 3, at 440.

23. For a discussion on the importance of knowledge, which is processed by practical actions and distributed over many people, see F.A. Hayek, The Use of Knowledge in Society, 35 Ам. Econ. Rev. 519, 530 (1945). 
eral knowledge. ${ }^{24}$ The complex processes of production and its continuous selftransformation demanded ex ante rules for the standardized balancing of interests and professional definitions of technical norms. ${ }^{25}$ The technical standard is the new hybrid rule that normalizes information and evaluations, and, as such, creates a new factual infrastructure for administrative decisionmaking processes.

\section{B. The Structuring Role of the "Administrative Act" in Continental European Doctrine}

From a European point of view, one might add that traditional administrative decision making was less oriented toward steering society according to legal norms than was often supposed in retrospect. The central reference of public law to the idea of "order" was paradigmatic for the police law that delegated a broad leeway of discretion to administrative actors, which, in turn, allowed situated decision making by binding administrative acts (Verwaltungsakte). Central to this approach is the processing of decisions from case to case with a view to the creation of a practical experience, which was the equivalent of private experience distributed throughout society. The objectivity and rationality of administration is derived not from the general legal norm but by a process of self-binding by decisions and the inherent relational rationality of the horizontal links generated from case to case. Decision making "requires closure" ${ }^{26}$ inasmuch as it derives legitimacy from internal coherence and not primarily from obedience to a general legal norm (model).

Processing its observations of reality through the medium of files, which register cases and decisions, public administration creates constraints on future decisions inasmuch as they have to be made continually on a case-by-case basis, an approach that presupposes the stability of a normal order and the patterns and conventions of which it consists. A decision is only possible against the background of such a presupposition of stability that imposes a certain view of reality, which again finds its expression in the ways of accumulating knowledge in files. In this mode, a specific public experience that corresponds to private experience and its "social epistemology" is generated. ${ }^{27}$ Each paradigm of decision making in history

24. See Stephen P. Turner, Liberal Democracy 3.0: Civil Society in an Age of Experts 59-61 (2003).

25. See Karl-Heinz Ladeur, The Integration of Scientific and Technological Expertise into the Process of Standard-Setting According to German Law, in The Integration of Scientific Expertise into Standard Setring 77, 90 (Christian Joerges \& Ellen Vos eds., 1997).

26. Brian J. Loasby, The Division and Organisation of Knowledge, 12 Eur. J. Econ. \& Soc. Sys. $143,153(2000)$.

27. Steve Fuller, Social Epistemology 273-74 (1988). 
demands a cognitive infrastructure that is closely linked to the ways that knowledge is generated and stabilized within society as a whole. Decision making in the liberal society is thus not only characterized by its reference to cases, but also its generation and processing of experience, conventions, and patterns that stabilize trust in the reliability of social observations of reality.

The "administrative act" in French and German administrative law is less the medium of "application" of a general statute in a specific case than, instead, a form that breaks with the immediacy of the weighing and balancing approaches of the "state science" (Staatswissenschafi) of the monarchical state, which claimed to be able to have access to the public interest of society as a whole by imposing rules and implementing common goals formulated from an external point of observation of society.

The administrative act corresponds to the private will (Willenserklärung) in private law, which is the cornerstone of modern contract law. It is not by chance alone that the authors of the books on the new doctrine of private law are also the authors of the modern doctrine of public law, such as Carl Friedrich Gerber. ${ }^{28}$ The administrative law of the nineteenth century is embedded in a movement toward the autonomy of the legal system, which leaves aside the traditional links to local values, state interest, and state science of the common good.

\section{Experience and the Framing of the Cognitive Infrastructure of}

\section{Public Administration}

The administrative act is always limited by the effect of the framing of the observations and information created by the continuity of social expectations, patterns of attributing responsibility, presuppositions of probability, codified relations of cause and effect, normative conventions, and other rules that make up the social epistemology and the cognitive infrastructure of society, which are applied and not reflected in administrative processes. This was the social frame of reference for the administrative act in the nineteenth century. ${ }^{29}$ It presupposed an implicit intermediary level of construction of reality that was situated between the empirical realm of mere facts and the normative rules in a stricter sense. It allowed for the flexibility of the application of law following individual cases governed by decisions. This meant that the normative order was linked to a cognitive

28. See generally C.F. Gerber, Grundzüge Eines Systems des Deutschen Staatsrechts (1865) (developing a system of public law following the doctrinal structures of private law).

29. MAYER, supra note 2, at 50. 
order of society that involved a framing effect on decisionmaking processes. Knowledge, in this sense, is a kind of "free floating quality of expectation," 30 which is formulated and reformulated "in the normal process of communication by specification in situations." ${ }^{31}$ This is the mode of self-generation of experience, which is a practical type of knowledge generated from practical action, and formulated with a view to consecutive action, which, at the same time, permits us to see its limitation by imposing the constraint of practicality. ${ }^{32}$ Private will and administrative acts are the instruments of making decisions on the basis of diffused and distributed knowledge..$^{33}$ They allow for binding uncertainty in the process of the self-transformation of society as well as within the open horizon of societal expectations for the future. This "autological structure" ${ }^{\text {"34 }}$ of decision making is imposed on the continuity of processing, binding constraints, and openness for innovation simultaneously without ending in disorientation. The concepts of danger in public law and negligence in private law are paradigmatic examples ${ }^{35}$ of bridging concepts between proto-normative rules of practice, knowledge rules, and societal expectations on the one hand, and normative stabilization of order on the other. Danger is the expectation of harm on the basis of the accepted links of causes and detrimental effects, which refer to a social concept of harm as a depreciation of stable normal values and goods in particular. ${ }^{36} \mathrm{~A}$ mere contribution to a complex process of transformation of goods, which has no clear attribution either to the state or to individuals (e.g. air quality), cannot be regarded as harm. In this case, the reference to a normal state and the observation of an individual deviation from normality would be excluded. The administrative act that corresponds to this construction of reality is, by itself, specified as an individual intervention into the causal chain of events that leads to harm. Complex effects of multi-causality cannot be addressed by the traditional version of the administrative act. The recent agendas of environmental law, for example, demand a reformulation of both the cognitive infrastructure and the normative structure of administrative deci-

30. Niklas Luhmann, Die Wissenschaft der Gesellschaft 147 (1990).

31. Id. at 333 .

32. Id. at 122 .

33. For the dispersed character of practical knowledge, see Hayek, supra note 23, at 530.

34. Luhmann, supra note 30 , at 360 .

35. Karl-Heinz Ladeur, Coping with Uncertainty: Ecological Risks and the Proceduralization of Environmental Law, in Environmental Law and Ecological Responsibility: The Concept and Practice of Ecological Self-Organization 299, 299-301 (Gunther Teubner, Lindsay Farmer \& Declan Murphy eds., 1994).

36. Albert C. Lin, The Unifying Role of Harm in Environmental Law, 2006 Wis. L. Rev. 897, 901. 
sion making. This presupposes a comprehensive concept of risk ${ }^{37}$ and precaution, which spans a bundle of situations with a plan-like strategy. ${ }^{38}$

\section{The Rise OF Expert KNOWLedge}

\section{A. The Role of Public Administration in the Management of Knowledge in Liberal Society}

In a similar vein, this evolution can be observed with reference to the notion of negligence in private law. Negligence is also based on proto-normative practices of action in different domains, which generate rules of professions, technical constraints, rules of thumb, conventions, and mutual expectations on the basis of which normative attribution of responsibility is made possible. ${ }^{39}$ Only those concatenations of causes and effects that can be attributed to human action and evaluated as a deviation from established standards and patterns of behavior can be regarded as negligent. Normative and cognitive elements are intertwined in this judgment. ${ }^{40}$ In public law, the administrative act corresponded to the "free floating quality of expectation "'il inherent in societal experience; the closure of the decision consisted in the fixation on the sharp intervention into a causal process and specified the mode of operation with knowledge. Distant risks and long and entangled networks of causality were beyond the domain of the administrative act.

The type of fexible knowledge that was generated on a case-by-case basis in Europe during the liberal epoch was part of a common knowledge that was enshrined in, and processed by, "communities of practice" ${ }^{\text {"42 }}$ and their conventions and patterns of action. In Germany, for example, the practical conventions in the

37. See Judgment of February 17, 1984, BVerwG, 69 BVerwGE 37, 42. For information on the concept of risk in German doctrine, see Rainer Wahl, Herausforderungen und Antworten: Das Öffentliche Recht der Letzten Fünf Jahrzehnte 71 (2006).

38. See generally Karl-Heinz Ladeur, The Introduction of the Precautionary Principle into EU Law: A Pyrrhic Victory for Environmental and Public Health Law? Decision-Making Under Conditions of Complexity in Multi-Level Political Systems, 40 Соммоn Mкт. L. Rev. 1455 (2003) (describing the lack of structuring in environmental precaution).

39. Id. at 901 .

40. Id. at 903 .

41. Luhmann, supra note 30, at 147.

42. Patrick Cohendet \& Patrick Llerena, Routines and Incentives: The Role of Communities in the Firm, 12 Indus. \& Corp. Change (Special Issue) 271, 273 (2003); accord Carsten Osterlund \& Paul Carlile, Relations in Practice: Sorting Through Practice Theories on Knowledge Sharing in Complex Organizations, 21 In Fo. Soc'y 91, 92 (2005). 
field of construction of houses (both aesthetical and practical) were mainly local and not very dynamic or modern in the nineteenth century. This fact hampered innovation and learning on the one hand and public control of safety standards on the other. Prussia, in particular, successfully tried to stimulate private and public activities that would harmonize this knowledge basis at a more general level and break up the narrow-minded links to local interests in small industry. ${ }^{43}$ The outcome of this process of public stimulation of the stability of a common knowledge in the field of construction standards, or standards for the use of electricity, was the establishment of private professional communities at the state level, which discussed informal practical rules and formulated recommendations for the practice that were the predecessors of subsequent explicit standards. ${ }^{44}$ This common knowledge could be used both by private and public actors. Once this process had been successfully initiated, the leading role was taken over by private persons and associations that worked as a kind of information "brokers. ${ }^{245}$ In the field of deciding on licenses for industrial activities, the administrative act was only possible on the basis of this mode of harmonization and stabilization of knowledge.

\section{B. Government by Experts and Standard-Setting}

The next evolutionary step in the United States led to the rise of government by experts during the New Deal era ${ }^{46}$ Practical knowledge could no longer be institutionalized in the mode that had been established in the nineteenth century. Along with the more rapid process of the self-transformation of industry, its generation had to be rendered more dynamic and reflexive as well. Administrative law had to be hammered out and codified explicitly in standards that were, from the outset, meant to serve administrators and private actors in a more general way. Regulation was a new type of more dynamic coordination of the knowledge basis of societies and the normative rules for decision making in a comprehensive planning rationality, which was designed to avoid more complex risks and allow for more abstract management of big enterprises. In many fields, decision making in a case-by-case mode seemed to be insufficient and the knowledge basis of society was regarded as

43. See generally Karl-Heinz Ladeur, The Postmodern Condition of Law and Societal "Management of Rules": Facts and Norms Revisited, 27 ZeItschrift Für ReChtssoziolocie 87 (2006) (analyzing the changing relationship between facts and legal regulation).

44. Miloš Vec, Recht und Normierung in der Industriellen Revolution 226 (2006).

45. F. Creplet, O. Dupouet, F. Kern, B. Mehmanpazir \& F. Munier, Consultants and Experts in Management Consulting Firms, 30 Res. Pol'y 1517, 1518 (2001).

46. Stewart, Administrative Law in the Twenty-First Century, supra note 3, at 440. 
lagging behind the requirements of modern industry and its management. A strategic element had to be introduced into public and private decision making. A more or less situational type of knowledge, which was still managed and developed by communities of practice, was no longer an adequate way for the institutionalization of the creation and processing of societal knowledge. A more general explicit harmonization of rules and standards was required by both industry and public administration. Public leeway for the administrative formulation of explicit standards and flexible modes of reception for private norms had to be acknowledged. ${ }^{47}$ The legal control of this new regulatory practice was shifted to procedural requirements of hearing, detailed reasoning, and plausibility. ${ }^{48}$

In German courts, practice standards, which determine safety requirements, are often regarded as "anticipated expertise" analogy to traditional expertise introduced in individual cases. Judicial control of such expertise is limited to rules of plausibility, procedural requirements, and a ceteris paribus clause. ${ }^{50}$ This new version of expertise lays open a new problem that is raised by the transition from the presupposition of implicit knowledge which is administered in broad communities of practice to the reflection of knowledge in explicit standards. This evolution develops on the basis of a fragmentation of knowledge in private industry. Increasingly, more advanced dynamic industries are separated from the less dynamic small industries that still follow the traditional analogical mode of knowledge generation and distribution. However, at the level of society as a whole, the link between decision making and the processing of situational specification of practical knowledge on a case-by-case basis is replaced by a more abstract knowledge that is managed by professional communities with regard to the requirements of the more advanced sectors of industry. ${ }^{51}$ The common formulation of standards cannot be reduced to forms of practical experience or a general communication of expertise alone. It is characterized by explicit reflection on the future necessities of technology and takes on a reflexive element

47. See Judgment of Aug. 8, 1978, BVerfG, 49 BVerfGE 89, 139.

48. Martin Shapiro, The Frontiers of Science Doctrine: American Experiences with the Judicial Control of Science-Based Decision-Making, in The Integration of Scientific Expertise into Standard Setting, supra note 25, at 325, 340 [hereinafter Shapiro, Frontiers]; Stewart, Administrative Law in the Twenty-First Century, supra note 3, at 442; see also Martin Shapiro, The Giving Reasons Requirement, 1992 U. CHI. L. Rev. 179 (giving an overview of the evolution of the shift of judicial control to procedural requirements and its drawbacks).

49. See Judgment of Feb. 17, 1978, BVerwG, 55 BVerwGE 250, 256.

50. For the U.S. perspective, see Shapiro, Frontiers, supra note 48, at 340.

51. See Osterlund \& Carlile, supra note 42, at 94. 
of proactive observation of industry. ${ }^{52}$ The role of professional communities is separated from the traditional communities of practice by their proactive management role, which strengthens the binding character of standards by explicit (though flexible) normative principles of transformation into legal practice. At the same time, they have to be distinguished from the function of science, which is reserved to universities. This model of institutionalization of knowledge in standard-setting uses different forms that need not be described in detail here.

However, in retrospect, the thesis can be ventured that, in modernity, knowledge has always been framed by a societal distribution process of construction, which accompanies processes of normative decision making but which cannot be made completely explicit. Societal knowledge is implicitly embedded in a pool of variety that can be punctuated by individual decisions and, at the same time, opens the horizon of expectation for new possibilities. ${ }^{53}$

The new form of the institutionalization of knowledge of industrial society is characterized by the phenomenon of a proactive management of cognitive rules in more specialized professional communities that specify the knowledge basis for comprehensive groups of cases in a relational strategic rationality. ${ }^{54}$ If we link this assumption to the observation of the decisions that have to rest on the knowledge basis, we have to acknowledge that public administration can no longer draw its orientation directly from the broad practical pool of variety as it did in the past, and then proceed from case to case and set up chains of decisions by analogical thinking. ${ }^{55}$

\section{Public-Private Cooperation in Knowledge Management}

Administrative acts have to be integrated into a comprehensive logic of planning. This is not to be misunderstood as a "master plan" to be executed by administrators. Instead, we are confronted by a type of "evolutionary planners," which have to be designed in an incremental mode. ${ }^{56}$ In this way, they still adhere to the

52. See generally Karl-Heinz Ladeur, supra note 43 (providing an overview of the evolution of standard-setting).

53. Luhmann, supra note 30 , at 333.

54. See J. Stanley Metcalfe, Knowledge, Understanding and the Epistemology of Innovative Firms, in Cognitive Developments in Economics 193, 203 (Salvatore Rizzello ed., 2003) (regarding the postmodern firm as an organization framed by its "embeddedness in a wider matrix of knowledge sustaining organisations").

55. See Turner, supra note 24 , at $39,61$.

56. John L. Pollock, Plans and Decisions, 57 Theory \& Decision 79, 99, 105 (2004). 
continuity of the relational rationality of processing options and respecting constraints that was characteristic of the liberal administration. However, the processing of knowledge is more comprehensive and follows a strategic logic. It is not by chance, though, that modern standards, in spite of their proto-normative character, are not normative in the stricter sense. They still remain cognitive in the sense of standardizing cause-effect patterns, setting rules of probability and presumption and distributing obligations of proof with a view to permitting action in conditions of uncertainty. ${ }^{57}$

The unavoidable element of public-private cooperation in producing and stabilizing societal knowledge develops in forms of participation of private actors in the management of standards, which takes on forms of a proactive design of practical knowledge. It is quite interesting to notice that private, public-private, and public procedures are used interchangeably. ${ }^{58}$ The greater the influence of private actors, the more importance is attributed to the rules of transfer of information into decision-making procedures. This importance of cooperation can be demonstrated also by the role of public-private contracts that are made between private standardizing organizations and the state. ${ }^{59}$ This explicit form of contract is also a repercussion of the quasi-contractual elements inherent in the social epistemology of the liberal epoch. The requirements of industrial practice were clearly an important stake in the social construction of knowledge and knowledge rules that were used in licensing procedures for machinery, for example. ${ }^{60}$

The new planning logic of standards also refers to the proportionality of safety requirements, which is also a version of a quasi-contractual element in licensing administration. It limits the imposition of clumsy restrictions on produc-

57. Lobel, supra note 17 , at 495 (arguing that "governance treats ambiguity as an opportunity").

58. This is due to the increasing process of knowledge fragmentation. JEAN-Marie Guérenno, L'Avenir de la Liberté: La Démocratie dans la Mondialisation 112 (1999). This evolution is also responsible for the shift from general regulation to small-scale contracting. See Lobel, supra note 15, at 377; see also Alfred C. Aman, Jr., The Limits of Globalization and the Future of Administrative Law: From Government to Governance, 8 IN D. J. Global LeGAL STud. 379, 399 (2001) (arguing that as a consequence of the new "transformative approach to administrative law, the line between the public and the private is blurred at best"); Stewart, Administrative Law in the TwentyFirst Century, supra note 3, at 451 (stating that the distinction between public and private is blurred and replaced by "cooperative fusion").

59. For a discussion of public-private contracts and standards for the capital market, see STEFfen Augsberg, Rechtsetzung zwischen Staat und Gesellschaft: Möglichkeiten differenzierter Steuerung des Kapitalmarktes 186-217 (2003).

60. For a discussion of the importance of social perspective and construction in knowledge generation, see Philip E. Tetlock, Expert Political Judgment: How Good Is Ir? How Can We KNow? 213-15 (2005). 
tion processes; at the same time, private industry has to fulfill the explicitly formulated safety standards. The understanding of "contracting" in postmodern public-private relationships should not be restricted to contracts in the formal sense of a reciprocal agreement between two separate parties. There is also a contractual element in the process of the production of public cognitive standards which consists in the fact that private experts act openly as parties to standardization procedures, whereas in the past this cooperation in the formulation of common knowledge ${ }^{61}$ was able to remain more hidden. The rise of the new forms of institutionalized cooperation in the process of the standardization of knowledge is due to the greater dynamics of knowledge production in modern industry, which demand more regulatory intervention by public administration.

This evolution is supported by the development of new methods of probabilistic operation with groups of cases with a view to the formulation of patterns of behavior and a management approach to the challenge of complexity. The concept of participation has also fuelled illusions about the inclusion of the citizen according to concrete situational relevance in standardization procedures. This is possible only to a limited extent because a broad participation may hamper the quasi-contractual element of the process of knowledge generation: if a person only has a negative stake, i.e. "not in my backyard," he or she is not a calculable partner in the bargaining process. Less interested citizens may stay away, whereas more active citizens may have a strong interest in presenting themselves as good representatives of interests common to the public as a whole, but may not be willing to indulge in a pragmatic process of bargaining. ${ }^{62}$ At the same time, participation may be incompatible with the logic of generating knowledge in professional communities.

As an interim conclusion, I would like to build a bridge to the role of the contract in both paradigms of social epistemology that have been described above. A quasi-contractual element has also been inherent in the experience-based knowledge of the liberal model. In this context, there was only limited room for explicit public contracts, with the exception of unusual forms of action that needed more flexibility. ${ }^{63}$ Although many problems in the past could be settled by private con-

61. See generally Patrick Cohendet \& Frieder Meyer-Krahmer, The Theoretical and Policy Implications of Knowledge Codification, 30 Res. PoL'y 1563 (2001) (describing the social embeddedness of knowledge generation and application).

62. See Hans-Heinrich Trute, Democratizing Science: Expertise and Participation in Administrative Decision-Making, in The Public Nature of Science Under Assault: Politics, Markets, Science and the Law 87, 97 (Helga Nowotny et al. eds., 2005).

63. It is interesting to look at different views in German administrative law. Compare Paul Laband, Book Review, 26 Archiv Für Öffentliches Recht 365, 366 (1910) (reviewing Max WeN- 
tracts between administration and industry, or other private actors, today, these contracts would mainly be regarded as public. The paradigmatic role of the administrative act and the presupposition of sovereignty paradoxically left much room for private contracts beyond the realms of hierarchy. This development has its reverse side in the narrow definition of the administrative act, which, for example, was not used to manage public subsidies and the like.

\section{The New Experimentalism and the Role of Public-Private Partnerships}

\section{A. Administrative Experiments and Contracting}

I would advance the hypothesis that the search for the role of the contract in public administration is not productive. It is much more important to have a better understanding of its embedding in the paradigms of the relationships between public and private actors on the one hand and the social epistemology that dominates both the private and the public use of common knowledge in society on the other. We have to pay attention to the general philosophy of regulation ${ }^{64}$ and the expectations that are inherent in the cognitive pool of variety.

In liberal administrative law too, we had a practice of cooperation between public and private actors in the process of codifying a common knowledge. However, the number of potential trajectories of evolution was not yet so numerous that an explicit strategic intervention seemed to be unnecessary. The use of knowledge in a single case was then processed on a case-by-case basis, which allows for decision making by way of administrative acts that leaves the active role of private industry and other private actors in the dark because of its generalized implication in a broad practice of producing experience. It is only with the rise of a new model of administration of the New Deal type that a development of a more explicit practice of reflection of knowledge production comes to the fore. Paradoxi-

zel, Zur Lehre der vertragsmässigen Elemente der Reichsverfassung (1909)) (taking the view that the state was able to step down from the higher levels of sovereign decisionmaking (administrative act) to the "lower level" of contracting), with Otto Mayer, Zur Lehre von offentlichrechtlichen Verträge, 3 ARCHiv Für ÖFfentliches Recht 3, 5, 33 (1888) (assuming that a monopoly of the "administrative act" for the realm of public decisionmaking was not meant to exclude the use of private contracts for the "fiscal" interest of the state).

64. For a discussion on the new relationship between contracting and regulation, see VINCENTJoNEs, supra note 20 , at 117-24. 
cally, this evolution corresponds to the expansion of public law and the rise of administrative contracts and quasi-contractual forms of public-private coordination (e.g. negotiated regulation). However, the role of the contract in public law cannot be analyzed with regard to legal doctrine alone. A broader approach to the description of the relationship between public and private under conditions of the self-transformation of society has to be formulated. A look at the evolution of the generation and stabilization of knowledge deserves priority in this regard because it finds its repercussion in the relationship between administration and private society. The common knowledge used both by private and public actors is the framework for the evolution of legal forms of coordination of state and society. The changing rationality of cooperation demonstrates the new hybrid form of an intertwinement of general and specific knowledge in projects, a form which undermines the hierarchical separations characteristic of the knowledge systems of the past. Clearly, this approach creates not only new possibilities but also new risks, because these knowledge clusters are less accessible to observation and evaluation from the outside; control knowledge, in many respects, can be generated only within such epistemic communities and cannot be collected from detached expertise. Many technological projects today can no longer be analyzed in advance because it is only by practical development, and not by observation from the outside, that the required knowledge can be accessed.

Against this background, the new role of contracts may be understood as arising from a further evolution of the cognitive infrastructure of society. Contracts are a form of public-private coordination in conditions that are characterized by a rise of the experimental design of projects and of the operation on the basis of a cognitive infrastructure that is dominated by fragmented networks of interrelationships that find their repercussion in border-spanning "epistemic communities" of people generating knowledge in a project-like form of cooperation. Both within administration and outside it, this new type of knowledge generation can be adopted by new versions of contract.

I have focused my paper on the transformation of public-private cooperation in the process of knowledge generation and the management of rules, which is based on the observation of the cognitive infrastructure of society mainly with a view to economic and technical regulation and its evolution within the last fifty years. However, the remodeling of the societal knowledge basis and its self-reflection in a social epistemology has a much broader impact on the development of the legal system beyond the domain of economic and technical regulation. The

65. Cohendet \& Llerena, supra note 42 , at 273. 
evolution of the knowledge base of society and its increasing complexity finds its repercussions in the reproduction of society as a whole also, and in the educational system or social welfare assistance in particular. ${ }^{66}$ The legal system, of course, has a role to play in the reproduction of societal knowledge and in the rules formulated by these social systems as well. In the primary societal model of knowledge reproduction in liberal society, the general experience-based paradigm, we find somewhat conventional and traditional modes of reproduction of societal knowledge and values that correspond to the paradigm of experience. This constellation supports the formation of the general expectation of individuals which accepts the stability of the "other" of society, a core of common knowledge, conventions, and values that are inculcated by families, public education, institutions of social assistance, and the like. The tertiary remodeling of the cognitive basis of society generates a much more complex relationship between the new rules of the knowledge society and its focus on networks and the experimental design of innovation.

\section{B. The Dark Side of Experimentalism: Decline of Common Knowledge as a Framework for Social Coordination?}

As a consequence of this new transformation of the cognitive infrastructure of society, we are confronted with an increasing uncertainty of the common knowledge and its potential of orientation for individuals. Increasingly, a general relativism spreads within the cultural institutions that gives the individual the illusion that any expectation of society, symbolic form of self-reflection, or formation of collective identity is subject to negotiation. From collective forms of negotiated regulation, we proceed to the generalization of the negotiation of the expectations imposed on individuals. This evolution finds its repercussion in the individualization of public education, which focuses on individual support and the dissolution of the objective requirements of knowledge generation and transfer. In this perspective, the rise of the concept of governance is much more problematic: it reflects the transformation of every individual or group into a cosmos of its own, which demands respect for its own identity, aspirations, and values. ${ }^{67}$ The formation of a kind of collective order under these conditions is attributed to

66. For a discussion on the use of public contracting in this field, see Vincent-Jones, supra note 20 , at $245,324$.

67. For the British perspective on the extension of contracting practices to education and social integration, see $i d$. at $245,324$. 
negotiation between all actors, be they collective or individual. ${ }^{68}$ Beyond the "epistemic communities" in technology and research, ${ }^{69}$ governance reflects the elimination of any major distinction between the state and societal actors. ${ }^{70}$ Each follows its own self-constructed identity and demands its respect from all others. The distinction between collective and individual interests crumbles and transforms all actors into a kind of mini-state. ${ }^{11}$ The transcendence of the former over the latter, the conflict of the heteronomy of a collective order, the autonomy of the individual, and the tension of normativity and facticity is supplanted by a general rule of balancing on a case-by-case basis, which, through its fixation on immediacy, blocks societal learning processes and creates the risk of a general entropy of conflicts and divergent opinions. Individual contracts or quasi-contractual arrangements on social inclusion, schooling, learning programs for jobless people, and educational assistance to parents with social problems, to name but a few instances, are a symptom of a loss of the distinctions and societal differentiation that dissolve a conception of a collective order into hybrid networks of interrelationships of heterogeneous actors. ${ }^{72}$ In this realm of entropy, the concept of public contract itself loses its meaning. It is no longer embedded in a "social epistemology" that frames the cognitive environment of individual expectations, but is regarded as being autological without any presupposition. This hypothesis stands in sharp contrast to the autology of the administrative act of the liberal epoch; it was closely linked to a general model of social experience, learning, and adaptation, ${ }^{74}$ which is still the case in the experimental logic of the epistemic communities, whereas the new rationale of public administration-not only in the fields of cognitive reproduction-is characterized by a perverse irrational sequence of intellectual fashions applied by fragmented groups - even within a single bureaucracy-which allow change only by the exhaustion of the actors or just by forgetting, but do not set up a structured frame of learning under conditions of growing complexity. ${ }^{75}$

68. Olivier Rey, Une Folle Solitude: Le fantasme de l'homme auto-construit 233 (2006).

69. Patrick Cohendet, Knowing Communities in Organizations, in Advancing Knowledge And the Knowledge Economy 91, 93 (Brian Kahin \& Dominique Foray eds., 2006).

70. GuÉhenNo, supra note 58, at 112.

71. REY, supra note 68.

72. See Vincent-Jones, supra note 20, at 245, 324.

73. See FulLER, supra note 27 , at 274.

74. Sabel \& Zeitlin, supra note 21 , at $19,28$.

75. For the German legal evolution, see WAHL, supra note 37, at 83 . The most popular reference to "learning" is ambivalent: "Learning" without a clear design of a strategy for action and of goals to be accomplished cannot be distinguished from "drift and opportunism." Errol Meidinger, The 


\section{Toward the Design of New Control Mechanisms for Public Contracting}

In my view, the observations on the social epistemology of the entangled rationalities of public and private action justify the approach that has been chosen here: as in private law, contract derives its meaning from general objective institutions and changing sets of common knowledge. Its proper role can only be observed if one does not set aside the transformations that are continuously going on in the embedding normative and social institutions. A positive version of this analysis might not consist in a nostalgic turn to the administrative law of the liberal society. Conventions, traditions, and cognitive expectations of the past cannot be reestablished if one takes into consideration the deep transformation that society has undergone. However, we are searching for a functional equivalent to the core of objectivity that lies at the bottom of the processing of the individual administrative act of the liberal society (and its contractual version). This functional equivalent can only be reformulated in a procedural rationality ${ }^{76}$ that is also the core element of the new mode of knowledge production in epistemic communities, which are, so to speak, the vanguard of the new form of knowledge management that is appropriate to the new cognitive infrastructure of postmodern society. In the past, the rationality of contracts was controlled by substantive law (steering behavior), or, in the pluralistic group society, by general substantive goals or participation in the processes of transforming the knowledge basis of society (standards). Both versions presuppose a certain objective logic of knowledge generation by society as a whole (liberal society) or by broadly encompassing representative groups (pluralistic society). The new embedding rationale of contracting should instead be seen in the experimental mode of knowledge generation that is institutionalized in the new postmodern private and public-private networks of innovation. ${ }^{77}$ As a general requirement for contracting beyond the well-structured technological projects, one could formulate the hypothesis that public contracts should be controlled by procedural requirements that are modeled on the example of networks of innovation in the following sense. As we can no longer presuppose the stable substantive rationality of a set of general truths, values, rules, and conventions, we have to expect the openness of public contracts in an experimental setting. However, experiments can only be accepted on the basis of

Administrative Law of Global Private-Public Regulation: The Case of Forestry, 17 Eur. J. INT'L L. 47, 86 (2006).

76. For a discussion on the proceduralization of the accountability of contracting, see VINCENTJones, supra note 20 , at 312 .

77. See generally Karl-Heinz Ladeur, supra note 43 (providing an overview of the evolution of knowledge generation in postmodern societies). 
several procedural requirements. They have to formulate a clear design: What could be the outcome of a contract on social inclusion? How could success or failure be observed? How could evaluation and monitoring ${ }^{78}$ be guaranteed? How could learning from failure-which cannot be avoided ${ }^{79}$ - be made possible? How could benchmarking be established as a control practice? How could learning beyond administrative competencies be supported? How could inter-administrative networks of knowledge generation (joint administration) be established? The hitherto established separation of competencies had presupposed the possibility of a practice of distributed knowledge generation and the separation of general steering knowledge at the top, management knowledge at the middle, and executive knowledge at the basic level of administration. In private firms, this separation has given way to the project-like bundling of various levels of knowledge. The rising importance of knowledge generation and of responsiveness to emergent norms and standards is incompatible with traditional concepts of accountability that cling to the illusion that the essential rules, norms, and values have to be formulated at a central democratic level, which should steer the process of administrative decision making as their application in practice. ${ }^{80}$ Accountability under complex conditions has to be proceduralized and reformulated as a requirement of a diversity of interdependencies and reciprocities of observation within overlapping networks. ${ }^{81}$

Against this background, the different processes of standardization can be regarded as steps toward a hybrid setting of private and public actors for the generation of new knowledge, which should be supplemented by more project-related administrative models of accumulation of experimental knowledge. In such a procedural setting, public contracting in multiple versions might be most productive, but contracts which are only characterized by vague goals on the basis of vague expectations are not helpful. They are incompatible with the requirements of trans-

78. See Aman, supra note 58, at 396; see also Stewart, Administrative Law in the Twenty-First Century, supra note 3, at 452 (highlighting that "network proponents" refer to "transparent systems of information" as a potential alternative to traditional methods of accountability; we should in fact go a step farther and stress the element of knowledge creation through design and experimenting-and not only "transparency," a concept which does not reflect the generative momentum of procedure).

79. Cf. Henry Petroski, Success Through Failure: The Paradox of Design 3, 5 (2006) (proposing that success is dependent "on anticipating how failure can or might occur").

80. Meidinger, supra note 75, at 85; see also Joshua Cohen \& Charles F. Sabel, Gobal Democracy?, 37 N.Y.U. J. INT'L L. \& Pol. 763 (2005).

81. See generally Cohen \& Sabel, supra note 80 (discussing a new logic of democratic experimentalism). 
parency in democracy. ${ }^{82}$ However, as elements of a collective strategy to raise the level of collective intelligence in both private and public fields of action, public contracts can be extremely useful. Public contracting should not be reduced to a phenomenon of the much decried "totalizing" tendencies of the economic rationality. ${ }^{83}$ It should also be interpreted as a consequence of the permeability of the contractual form for different "discourses." The evolution of the private contract under conditions of postmodernity, which has been sketched above, has contributed to this process. The language of contracting allows a productive dynamic of mutual interrelationships between private and public discourses to come to the fore. ${ }^{84}$

However, the increasing fragmentation of the knowledge basis of society and the pluralization of knowledge-generation procedures, the hybrid coupling of facts and design of search processes, and the importance of overlapping networks and their heterarchically distributed, project-oriented logic exclude any possibility of referring to a central point of observation ${ }^{85}$ that could guarantee a privileged position for an autonomous public rationality of norms that could be formulated beyond cooperation with private actors.

82. VinCENT-Jones, supra note 20, at $92,124$.

83. Gunther Teubner, In the Blind Spot: The Hybridization of Contracting, 8 Theoretical InQ. IN L., Jan. 2007, 51, 67-68, available at http://www.bepress.com/cgi/viewcontent.cgi?article $=1143 \&$ context $=$ til.

84. See id. at 67-71 (discussing the conflict between different discursive logics in new types of private contracting such as contracts based on expertise, which is distributed to the public).

85. See Georges Balandier, Le Désordre: Éloge du mouvement 241 (1988). 


\section{inscribe \\ e-publishing portal of IU Press}

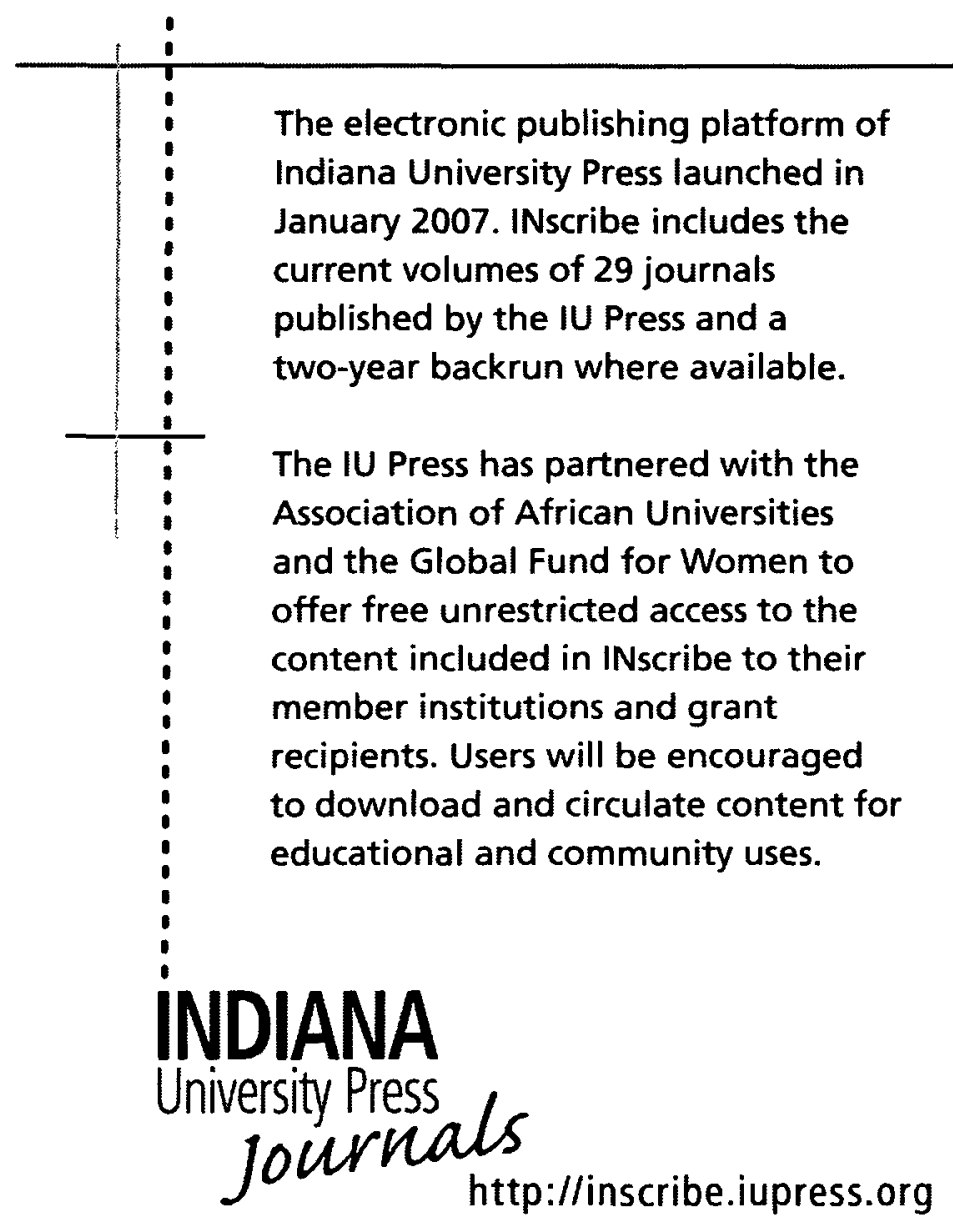

